\title{
An electrophysiological study on children and young adults with Alport's syndrome
}

\author{
Brett G Jeffrey, Mark Jacobs, Gabriella Sa, T Martin Barratt, David Taylor, Anthony Kriss
}

\begin{abstract}
Alport's syndrome is characterised by progressive haematuric nephritis and high tone sensorineural hearing loss. Ocular signs are variable, the most consistent findings being anterior lenticonus and retinal flecks in the macula and mid peripheral areas. Previous electrophysiological studies on patients with Alport's syndrome have mostly been on adult patients undergoing haemodialysis, or after renal transplantation. A group of young patients with Alport's syndrome were studied to assess if early electrophysiological changes were detectable. A total of 20 patients (15 males and five females) between the ages of 3.5 and 22 years (mean 12.7 years) were examined and compared with control subjects. Visual evoked potentials and electroretinograms were obtained following flash and pattern reversal stimulation. Electro-oculograms were also recorded. No significant electrophysiological changes were found in any of the $\mathbf{2 0}$ patients, including four who had visible fundus changes.

(Brf Ophthalmol 1994; 78: 44-48)
\end{abstract}

Alport's syndrome is an $\mathrm{X}$ linked disorder affecting basement membrane collagen. ${ }^{1-3}$ The syndrome is characterised clinically by progressive haematuric nephritis and high tone sensorineural hearing loss. Ophthalmic changes have also been reported, the most consistent findings being anterior lenticonus and flecks in the macular and mid peripheral retina. ${ }^{4-11}$ Retinal abnormalities less frequently reported include drusen in Bruch's membrane, retinal pigment epithelium dystrophy, macular degeneration, and hyperfluorescent window defects on fluorescein angiography. ${ }^{4611-13}$

The majority of males with Alport's syndrome have haematuria and high tone hearing loss by the age of 10 years. Renal failure tends to occur in the second to fourth decade of life..$^{914-16}$ Females exhibit greater phenotypic variation. Some females are as severely affected as males, while others have persistent haematuria as the only symptom. ${ }^{14-16}$ The variable gene expression seen in females can be explained by random inactivation of the $\mathrm{X}$ chromosome (Lyon hypothesis). ${ }^{17}$

Flinter and Chantler $^{17}$ reported a high incidence of ocular changes ( $72 \%$ males, $38 \%$ females) in a group of 188 patients with Alport's syndrome. Other studies have found a lower incidence of ocular changes ranging between $11 \%$ and $43 \% .^{79} 1518$

Reports of electrophysiological findings in patients with Alport's syndrome are also varied. Normal electroretinograms (ERGs) have been reported in about $55 \%$ of the total of 29 patients with Alport's syndrome reported in the literature, ${ }^{5710^{-12} 19}$ and subnormal ERG amplitudes in the remaining $45 \% .^{7811-132021}$

Most studies find that the electro-oculogram (EOG) is normal. ${ }^{57101119-21}$ However, Hochgesand $e t a l^{12}$ described subnormal light rises in association with retinopathy in three patients, and Perrin $e t a l^{7}$ found that one patient out of seven had both a subnormal EOG light rise and a subnormal ERG amplitude.

Only a few studies have assessed the visual evoked potential (VEP) in patients with Alport's syndrome. Setälä $e t$ al ${ }^{13}$ recorded responses to flash in two patients and found the VEP to be delayed in one patient and normal in the other. Zylbermann et $a l^{8}$ reported a VEP with subnormal amplitude but normal latency in one young female with Alport's syndrome.

Most previous studies have reported electrophysiological findings in adult patients with Alport's syndrome undergoing haemodialysis or after renal transplantation. There is little information on the incidence of electrophysiological changes in the broad range of unselected patients with Alport's syndrome, or in young patients with the disorder. We have recorded VEPs, ERGs, and EOGs in 20 young patients with Alport's syndrome to investigate the prevalence of electrophysiological changes in children and young adults. The 20 patients were reviewed by the departments of ophthalmology, nephrology, genetics, and audiology. The electrophysiological results presented here formed part of the patients' ophthalmic review.

\section{Methods}

Letters explaining the study were sent to the parents of all children who were, or had been, under the care of the nephrology department at the Hospital for Sick Children. A total of 20 patients with Alport's syndrome (15 male, five female) aged between 3.5 and 22 years (mean 12.5 years) were examined.

In 13 of the patients the diagnosis of Alport's syndrome was confirmed by finding characteristic electron microscopic changes of the glomerular basement membrane on renal biopsy (the biopsy specimen was considered positive if diffuse glomerular basement membrane thickening and splitting were present). The remaining seven patients had a history of chronic haematuria and a sibling or a first cousin who was renal biopsy positive for the disease.

In all patients, ERGs and VEPs were recorded simultaneously for both pattern reversal and flash stimulation. A reversing checkerboard $\left(50^{\prime}\right.$ checks, $3 \mathrm{rev} / \mathrm{s}$, contrast $90 \%$ ) was displayed on a television screen. At the viewing distance of 1 metre, the stimulation field subtended $28^{\circ}$ 
horizontally, and $20^{\circ}$ vertically. In addition, a flash stimulus was presented at the rate of 3 per second using a hand held lamp (Grass PS22, intensity 4) placed $15 \mathrm{~cm}$ from the patients' eyes.

Pattern ERGs (PERGs) and flash ERGs (FERGs) were recorded from 14 patients using gold foil electrodes inserted in the lower fornix. A topical anaesthetic (amethocaine $1.0 \%$ ) was administered before electrode insertion. Silver/ silver chloride electroencephalogram (EEG) electrodes placed on the lower eyelid, were used to record skin ERGs in the remaining six patients (five were less than 8 years old) since they would not accept gold foil electrodes.

The flash and pattern VEPs were recorded from two silver/silver chloride EEG electrodes placed on the occipital midline: one at $\mathrm{Oz}(10-20$ System, approx $3.5 \mathrm{~cm}$ above the inion) and the other at the inion.

All active ERG and VEP electrodes were referred to a midfrontal electrode $(\mathrm{Fz})$. The recording amplifier bandpass was set between 3 $\mathrm{Hz}$ and $125 \mathrm{~Hz}$. A total of 128 pattern reversals or flashes were summed for each averaging run.

A Cadwell ganzfeld stimulator was used to elicit single flash ERGs in 12 of the patients who would accept gold foil electrodes. Patients' pupils were dilated (phenylephrine $2.5 \%$ ) and dark adapted for 20 minutes. Single flash ERGs were recorded under scotopic conditions to dim white light $\left(0.4 \mathrm{~cd} . \mathrm{m}^{-2} . \mathrm{s}\right.$ at the bowl surface $)$ and to bright white light $\left(3.73 \mathrm{~cd} \cdot \mathrm{m}^{-2} . \mathrm{s}\right)$. A total of four flashes separated by 30 second intervals were presented at each intensity. Photopic ERGs and $40 \mathrm{~Hz}$ flicker were recorded using bright flashes $\left(3.73 \mathrm{~cd} . \mathrm{m}^{-2} . \mathrm{s}\right)$ against a constantly illuminated white background $\left(78 \mathrm{~cd} . \mathrm{m}^{2}\right)$.

In 14 of the patients the ganzfeld was used to record the EOG. This was monitored every 2 minutes during a period of 15 minutes in darkness followed by 15 minutes under photopic conditions. Saccades were elicited by sequential fixation on light emitting diodes with 30 degrees separation. EOG change was assessed by com- puting the light peak to dark trough (Arden) ratio. In one very young patient aged $3^{1 / 2}$ years (case 9), saccades were recorded just for the short periods around the dark trough and light peak times normally found in healthy controls (that is, 8 to 12 minutes in darkness.followed by 6 to 9 minutes in light). ${ }^{22}$

Ganzfeld ERGs obtained with gold foil electrodes, and EOGs, were recorded in 10 healthy controls aged between 18 and 30 years (mean 23 years). While the age range and mean of the controls is higher than that of the patients, comparisons are valid since ERG amplitude, and the change in corneoretinal potential as measured by the EOG, are the same as adults by 12 months of age. ${ }^{23-26}$

Sixteen of the 20 patients tested had normal renal function while two were in chronic renal failure and two had received successful renal transplants. Neither of the patients in chronic renal failure had undergone haemodialysis.

Pattern and flash VEPs were recorded from 18 normal controls who were age matched in range and distribution to the group of patients with Alport's syndrome.

\section{Results}

A summary of relevant clinical details and electrophysiological findings for each of the patients is given in Table 1.

The amplitude and latency components of the ERG and VEP responses are shown in Table 2 for the group of patients with Alport's syndrome and for the control group.

The PERG amplitudes of the control group varied considerably and this is reflected by the wide 95\% confidence interval (Fig 1, dotted lines). The smallest PERG of $2 \cdot 7 \mu \mathrm{V}$ obtained in the Alport's group (case 1) using gold foil electrodes was not considered abnormally low. The P50-N95 amplitude components were also measured, as were P50 and N95 latencies (Table 1). The amplitudes and latencies of the PERG

Table 1 Summary of patient details

\begin{tabular}{|c|c|c|c|c|c|c|c|c|c|c|}
\hline Patient & Sex & $\begin{array}{l}\text { Age } \\
\text { (years) }\end{array}$ & $\begin{array}{l}\text { Renal } \\
\text { function }\end{array}$ & $\begin{array}{l}\text { Renal } \\
\text { transplant }\end{array}$ & $\begin{array}{l}\text { Hearing } \\
\text { loss }\end{array}$ & Lens & Retina & $E R G$ & $V E P$ & $E O G$ \\
\hline 1 & $\mathbf{M}$ & 22 & Normal & Yes $\times 2$ & Yes & PSCC & Flecks & - & LL & - \\
\hline 2 & M & 13 & Normal & - & Yes & - & - & - & - & - \\
\hline 3 & $\mathbf{M}$ & 17 & Normal & - & Yes & - & - & - & - & ND \\
\hline 4 & $\mathbf{M}$ & 20 & Normal & - & Yes & $\mathrm{AL}$ & - & - & LL & - \\
\hline 5 & $\mathbf{F}$ & 15 & Normal & Yes & Yes & PSCC & Flecks & - & - & - \\
\hline 6 & $\mathbf{M}$ & 21 & CRF & - & Yes & - & - & - & LL & - \\
\hline 7 & M & 7 & Normal & - & Yes & - & - & - & - & ND \\
\hline 8 & $\mathbf{M}$ & 5 & Normal & - & - & - & - & - & - & - \\
\hline 9 & $\mathbf{M}$ & 3 & Normal & - & - & - & - & - & - & - \\
\hline 10 & M & 16 & Normal & - & - & - & - & - & - & - \\
\hline 11 & $\mathbf{F}$ & 11 & Normal & - & - & - & - & - & - & - \\
\hline 12 & $\mathbf{F}$ & 17 & CRF & - & Yes & - & Depigmented & - & LL & - \\
\hline 13 & M & 15 & Normal & - & Yes & - & - & - & - & ND \\
\hline 14 & $\mathbf{F}$ & 12 & Normal & - & - & - & - & - & - & - \\
\hline 15 & $M$ & 4 & Normal & - & - & - & - & - & - & ND \\
\hline 16 & $\mathbf{M}$ & 8 & Normal & - & - & - & - & - & - & ND \\
\hline 17 & M & 9 & Normal & - & Yes & - & Flecks & - & - & - \\
\hline 18 & M & 12 & Normal & - & - & - & - & - & - & - \\
\hline 19 & $\mathbf{F}$ & 11 & Normal & - & - & - & - & - & - & - \\
\hline 20 & $\mathbf{M}$ & 13 & Normal & - & Yes & $\mathrm{AL}$ & - & - & - & - \\
\hline
\end{tabular}

ERG=electroretinogram

VEP $=$ visual evoked potential

EOG =electro-oculogram

$-=$ normal finding.

$\mathrm{CRF}=$ chronic renal failure

$\mathrm{AL}=$ anterior lenticonus.

PSCC = posterior subcapsular cataract.

$\mathrm{LL}=$ amplitude at lower limit of normal

$\mathrm{ND}=$ test not done. 
Table 2 Group averages and ranges for all tests

\begin{tabular}{|c|c|c|c|c|c|c|c|c|c|c|}
\hline \multirow[b]{3}{*}{ Test } & \multicolumn{4}{|c|}{ Patients with Alport's syndrome } & \multirow[b]{3}{*}{$n$} & \multicolumn{4}{|c|}{ Normal controls } & \multirow[b]{3}{*}{$n$} \\
\hline & \multicolumn{2}{|c|}{ Amplitude $(\mu V)$} & \multicolumn{2}{|c|}{ Latency (ms) } & & \multicolumn{2}{|c|}{ Amplitude $(\mu V)$} & \multicolumn{2}{|c|}{ Latency (ms) } & \\
\hline & Mean & Range & Mean & Range & & Mean & Range & Mean & Range & \\
\hline PERG P50 & & & & & & & & & & \\
\hline $\begin{array}{l}\text { foil } \\
\text { skin } \\
\text { PERG N95 }\end{array}$ & $\begin{array}{l}4 \cdot 3 \\
2 \cdot 2\end{array}$ & $\begin{array}{l}2 \cdot 5-6 \cdot 7 \\
0 \cdot 5-3 \cdot 8\end{array}$ & $\begin{array}{l}48 \cdot 6 \\
48 \cdot 4\end{array}$ & $\begin{array}{l}46 \cdot 8-51 \cdot 0 \\
45 \cdot 6-51 \cdot 6\end{array}$ & $\begin{array}{r}14 \\
8\end{array}$ & $\begin{array}{l}5 \cdot 1 \\
1 \cdot 7\end{array}$ & $\begin{array}{l}2 \cdot 8-8 \cdot 8 \\
1 \cdot 2-3 \cdot 4\end{array}$ & $\begin{array}{l}49 \cdot 0 \\
49 \cdot 4\end{array}$ & $\begin{array}{l}46 \cdot 8-52 \cdot 8 \\
46 \cdot 8-52 \cdot 8\end{array}$ & $\begin{array}{l}10 \\
10\end{array}$ \\
\hline $\begin{array}{l}\text { foil } \\
\text { skin } \\
\text { Pattern VEP } \\
\text { Flash VEP } \\
\text { Scotopic ERG }\end{array}$ & $\begin{array}{r}6 \cdot 3 \\
2 \cdot 8 \\
15 \cdot 4 \\
22 \cdot 6\end{array}$ & $\begin{array}{l}2 \cdot 6-10 \cdot 4 \\
1 \cdot 3-5 \cdot 2 \\
4 \cdot 7-27 \cdot 5 \\
9 \cdot 6-44 \cdot 4\end{array}$ & $\begin{array}{l}80 \cdot 7 \\
79 \cdot 8 \\
103 \\
101\end{array}$ & $\begin{array}{l}73 \cdot 2-96 \cdot 0 \\
68 \cdot 4-90 \cdot 0 \\
94-112 \\
80-133\end{array}$ & $\begin{array}{r}14 \\
8 \\
20 \\
20\end{array}$ & $\begin{array}{r}8 \cdot 4 \\
2 \cdot 0 \\
18 \cdot 5 \\
17 \cdot 6\end{array}$ & $\begin{array}{l}5 \cdot 0-12 \cdot 9 \\
1 \cdot 2-3 \cdot 5 \\
4 \cdot 8-39 \cdot 6 \\
6 \cdot 7-33 \cdot 0\end{array}$ & $\begin{array}{l}83 \cdot 7 \\
81 \cdot 5 \\
103 \\
109\end{array}$ & $\begin{array}{l}75 \cdot 0-97 \cdot 2 \\
69 \cdot 6-88 \cdot 8 \\
92-111 \\
78-126\end{array}$ & $\begin{array}{l}10 \\
10 \\
18 \\
18\end{array}$ \\
\hline $\begin{array}{l}\text { foila } \\
\text { skin } \\
\text { Photopic ERG }\end{array}$ & $\begin{array}{l}136 \\
31 \cdot 3\end{array}$ & $\begin{array}{l}80-205 \\
14 \cdot 8-49 \cdot 2\end{array}$ & $\begin{array}{l}39 \cdot 1 \\
38 \cdot 2\end{array}$ & $\begin{array}{l}37 \cdot 2-41 \cdot 4 \\
32 \cdot 4-40 \cdot 8\end{array}$ & $\begin{array}{l}14 \\
20\end{array}$ & $\begin{array}{l}153 \\
34 \cdot 1\end{array}$ & $\begin{array}{l}74-213 \\
20 \cdot 6-53 \cdot 2\end{array}$ & $\begin{array}{l}40 \cdot 5 \\
40 \cdot 0\end{array}$ & $\begin{array}{l}38 \cdot 4-42 \cdot 0 \\
38 \cdot 4-42 \cdot 0\end{array}$ & $\begin{array}{l}10 \\
10\end{array}$ \\
\hline $\begin{array}{l}\text { foil }^{\mathbf{a}} \\
\text { skin }^{\mathbf{a}} \\
\text { Single flash ERG }\end{array}$ & $\begin{array}{l}79 \\
24 \cdot 6\end{array}$ & $\begin{array}{l}41-127 \\
11 \cdot 4-36 \cdot 3\end{array}$ & $\begin{array}{l}31 \cdot 6 \\
31 \cdot 5\end{array}$ & $\begin{array}{l}28 \cdot 8-33 \cdot 6 \\
28 \cdot 8-33 \cdot 6\end{array}$ & $\begin{array}{l}14 \\
20\end{array}$ & $\begin{array}{l}90 \\
19 \cdot 2\end{array}$ & $\begin{array}{l}38-138 \\
11 \cdot 6-38 \cdot 1\end{array}$ & $\begin{array}{l}33 \cdot 1 \\
32 \cdot 5\end{array}$ & $\begin{array}{l}31 \cdot 2-36 \cdot 0 \\
30 \cdot 0-36 \cdot 0\end{array}$ & $\begin{array}{l}10 \\
10\end{array}$ \\
\hline $\begin{array}{l}\text { Scotopic } \\
\text { dim white } \\
\text { bright white } \\
\text { Photopic }\end{array}$ & $\begin{array}{l}274 \\
405\end{array}$ & $\begin{array}{l}201-422 \\
258-556\end{array}$ & $\begin{array}{l}69 \cdot 5 \\
49 \cdot 4\end{array}$ & $\begin{array}{l}57 \cdot 6-78 \cdot 0 \\
46 \cdot 0-52 \cdot 8\end{array}$ & $\begin{array}{l}12 \\
12\end{array}$ & $\begin{array}{l}298 \\
439\end{array}$ & $\begin{array}{l}146-364 \\
244-594\end{array}$ & $\begin{array}{l}69 \cdot 0 \\
52 \cdot 0\end{array}$ & $\begin{array}{l}61 \cdot 6-81 \cdot 2 \\
50 \cdot 4-55 \cdot 2\end{array}$ & $\begin{array}{l}10 \\
10\end{array}$ \\
\hline $\begin{array}{l}\text { bright white } \\
40 \mathrm{~Hz} \text { flicker }\end{array}$ & $\begin{array}{l}77 \\
17 \cdot 8\end{array}$ & $\begin{array}{l}32-125 \\
11 \cdot 0-26 \cdot 6\end{array}$ & $\begin{array}{l}26 \cdot 8 \\
25 \cdot 7\end{array}$ & $\begin{array}{l}27 \cdot 2-30 \cdot 0 \\
24 \cdot 7-27 \cdot 0\end{array}$ & $\begin{array}{l}11 \\
11\end{array}$ & $\begin{array}{l}87 \\
21 \cdot 4\end{array}$ & $\begin{array}{l}46-164 \\
7 \cdot 9-34 \cdot 9\end{array}$ & $\begin{array}{l}29 \cdot 0 \\
25 \cdot 8\end{array}$ & $\begin{array}{l}27 \cdot 6-31 \cdot 2 \\
25 \cdot 0-26 \cdot 8\end{array}$ & $\begin{array}{l}10 \\
10\end{array}$ \\
\hline
\end{tabular}

a Amplitude: a-b wave peak-to-peak.

Latency: b-wave only.

PERG= pattern electroretinogram.

PERG = pattern electroretinog
VEP = visual evoked potential.

P50 and N95 components were within normal limits for all the patients with Alport's syndrome.

Six patients (cases $1,3,4,6,7$, and 12) had pattern VEP (P100) amplitudes which were near the lower limit of normal $(4 \cdot 8 \mu \mathrm{V})$ (Fig 2). Four of these patients (cases 1, 4, 6, and 12) also had small flash VEPs. Cases 3 and 7 had much larger responses to flash stimulation than for pattern. All patients had normal VEP latencies to $50^{\prime}$ checks (Fig 3).

In the 12 patients with Alport's syndrome tested with the ganzfeld stimulator and gold foil electrodes, the mixed cone/rod ERG a-b wave amplitudes to bright single flashes were within normal limits and evenly distributed about the control mean (Fig 4). The rod mediated b-wave amplitudes to dim flashes presented under scotopic conditions, and the cone mediated amplitudes to bright flashes presented under photopic conditions, were also within normal limits. There were no significant a- or b-wave latency differences when comparing patients and controls. Photopic $40 \mathrm{~Hz}$ flicker amplitudes and latencies were similarly within normal limits (Table 1).

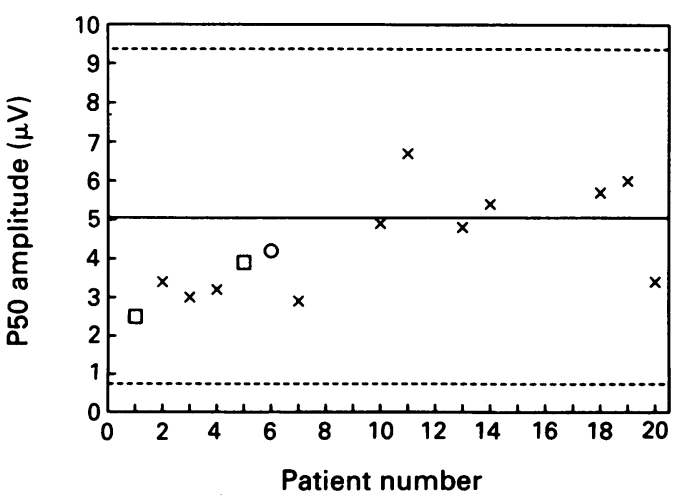

Figure 1 Pattern electroretinogram (PERG) (P50) amplitude to 50' checks. PERG recorded using gold foil electrodes. $(-)=$ mean amplitude of the control group; and $(--)=95 \%$ confidence interval. $(x)=$ patients with normal renal function; $(\mathrm{O})=$ patients in chronic renal failure;

(口)=patients who had received renal transplants.
The light peak to dark trough ratios (Arden index) of the EOG for the 15 patients tested are shown in Figure 5. All patients had ratios of $2 \cdot 2$ or higher, the lower limit of normal for our laboratory being $1 \cdot 85$. Patient 4 had a supernormal ratio of $4 \cdot 7$.

Figure 6 shows VEP, ERG, and EOG tracings from two of the patients. Case 6 was in chronic renal failure at the time of recording and had a renal transplant 3 months later. He gave smaller pattern VEP and flash ERG responses compared with both the normal control, and with case 11 who had normal renal function.

\section{Discussion}

The 20 young patients with Alport's syndrome in our series all had normal scotopic and photopic ERGs. Normal ERGs were found even though three patients had perimacular flecks typical of Alport's syndrome ${ }^{10}$ and one patient had a large depigmented area not involving the maculae.

Subnormal ERG amplitudes have been reported in patients without Alport's syndrome after chronic renal failure, ${ }^{2728}$ in those under-

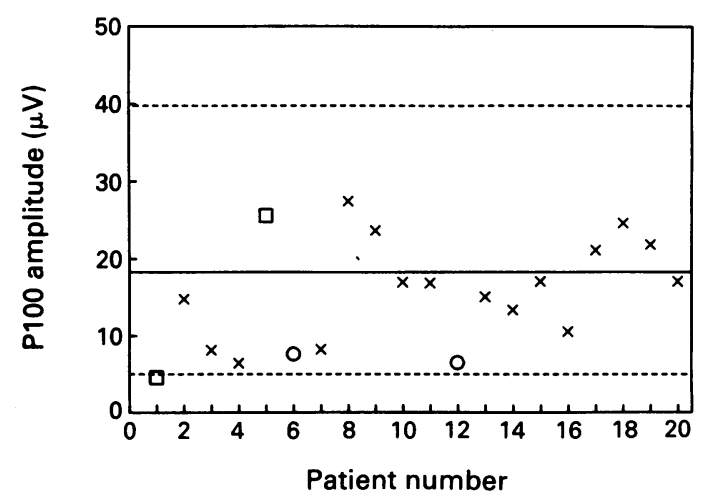

Figure 2 Pattern visual evoked potential (PVEP)

(P100) amplitude to 50' checks. $(-)=$ the mean amplitude of the control group; $(--)=$ the range of values from 18 age matched normal controls. Cases 1, 3, 4, 6, 7, and 12 are near the lower limit of normal $(4 \cdot 8 \mu V) .(X)=$ patients with normal renal function; $(O)=$ patients in chronic renal failure; and $(\square)=$ patients who had received renal transplants. 
Figure 3 Pattern visual evoked potential (PVEP) (P100) latency to 50' checks. All patients are within normal limits. $(-)=$ mean latency of the control group, and $(--)=95 \%$ confidence interval. $(x)=$ Patients with normal renal function; $(\mathrm{O})=$ patients in chronic renal failure; () patients who had received renal transplants.

\section{Figure 4}

Electroretinogram $(E R G)$ $a-b$ wave amplitudes to bright white single flashes presented under scotopic conditions and recorded using gold foil electrodes. Of the 12 patients tested under these conditions all were within normal limits.

$(-)=$ mean amplitude of the control group, and $(---)=95 \%$ confidence interval. $(X)=$ Patients with normal renal function; (O)= patients in chronic renal failure; and

$(\square)=$ patients who had received renal transplants.
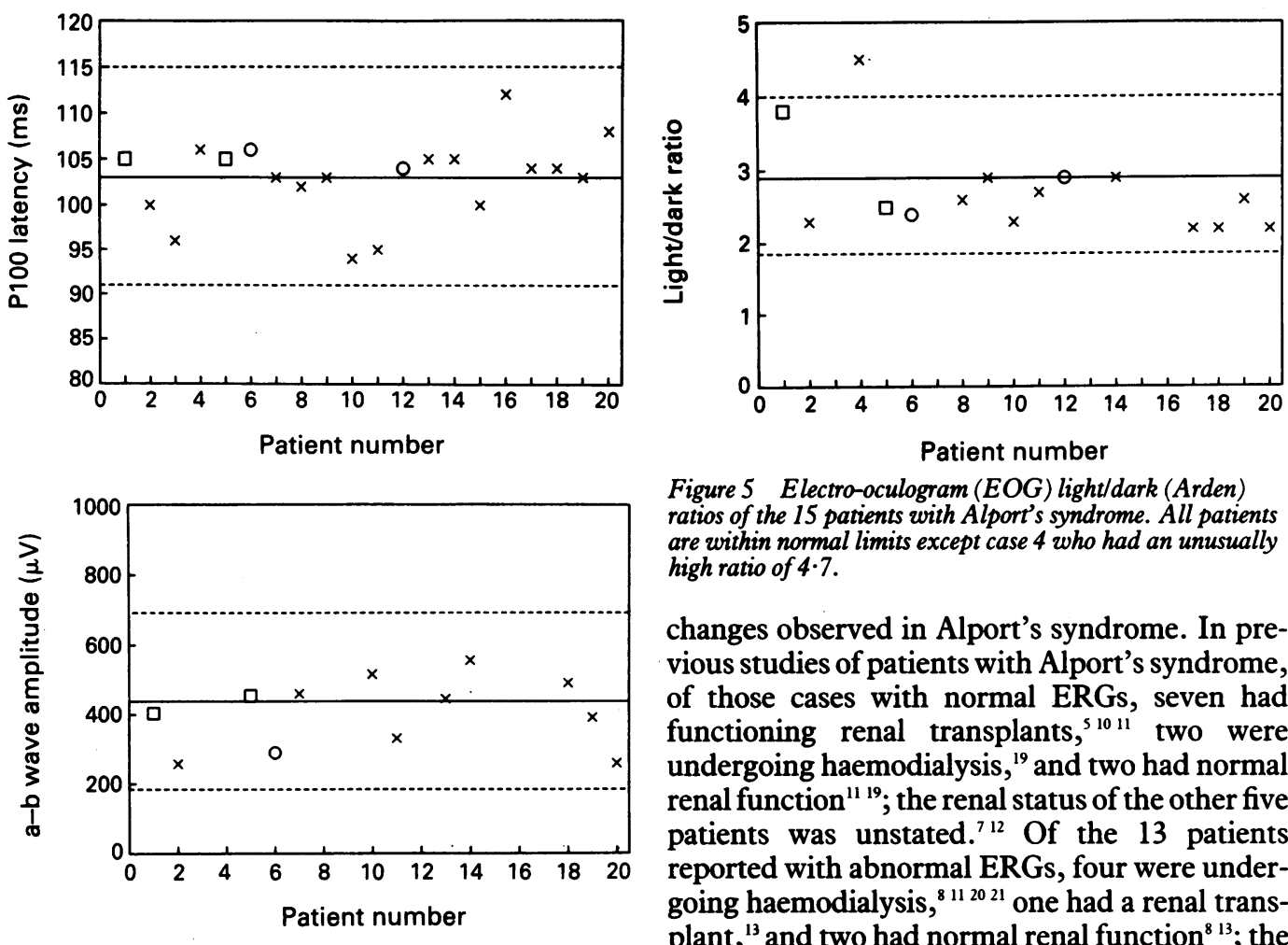

going haemodialysis, ${ }^{28-30}$ and after transplantation. ${ }^{31}$ Svěrák et $a l^{32}$ found that ERGs were generally abnormal after long term dialysis but tended to normalise after successful transplantation. It is possible that renal dysfunction and/or dialysis may have a role in producing ERG
Figure 5 Electro-oculogram (EOG) light/dark (Arden) ratios of the 15 patients with Alport's syndrome. All patients are within normal limits except case 4 who had an unusually high ratio of $4 \cdot 7$.

changes observed in Alport's syndrome. In previous studies of patients with Alport's syndrome, of those cases with normal ERGs, seven had functioning renal transplants, ${ }^{511}$ two were undergoing haemodialysis, ${ }^{19}$ and two had normal renal function ${ }^{11}{ }^{19}$; the renal status of the other five patients was unstated. ${ }^{72}$ Of the 13 patients reported with abnormal ERGs, four were undergoing haemodialysis, ${ }^{8112021}$ one had a renal transplant, ${ }^{13}$ and two had normal renal function ${ }^{813}$; the renal function in the remaining six patients was unstated. ${ }^{72}$

Our normal EOG results are in line with the majority of previous studies. 57810111920 Hochgesand $e t{ }^{12}$ described subnormal EOGs with normal ERGs in three young patients with Alport's syndrome (5-17 years). Fluorescein angiograms

$\begin{array}{lll}\text { RA } & \text { CS } & \text { KP } \\ \text { F } & M & F \\ 23 \text { yrs } & 21.6 \mathrm{yrs} & 11.5 \mathrm{yrs}\end{array}$

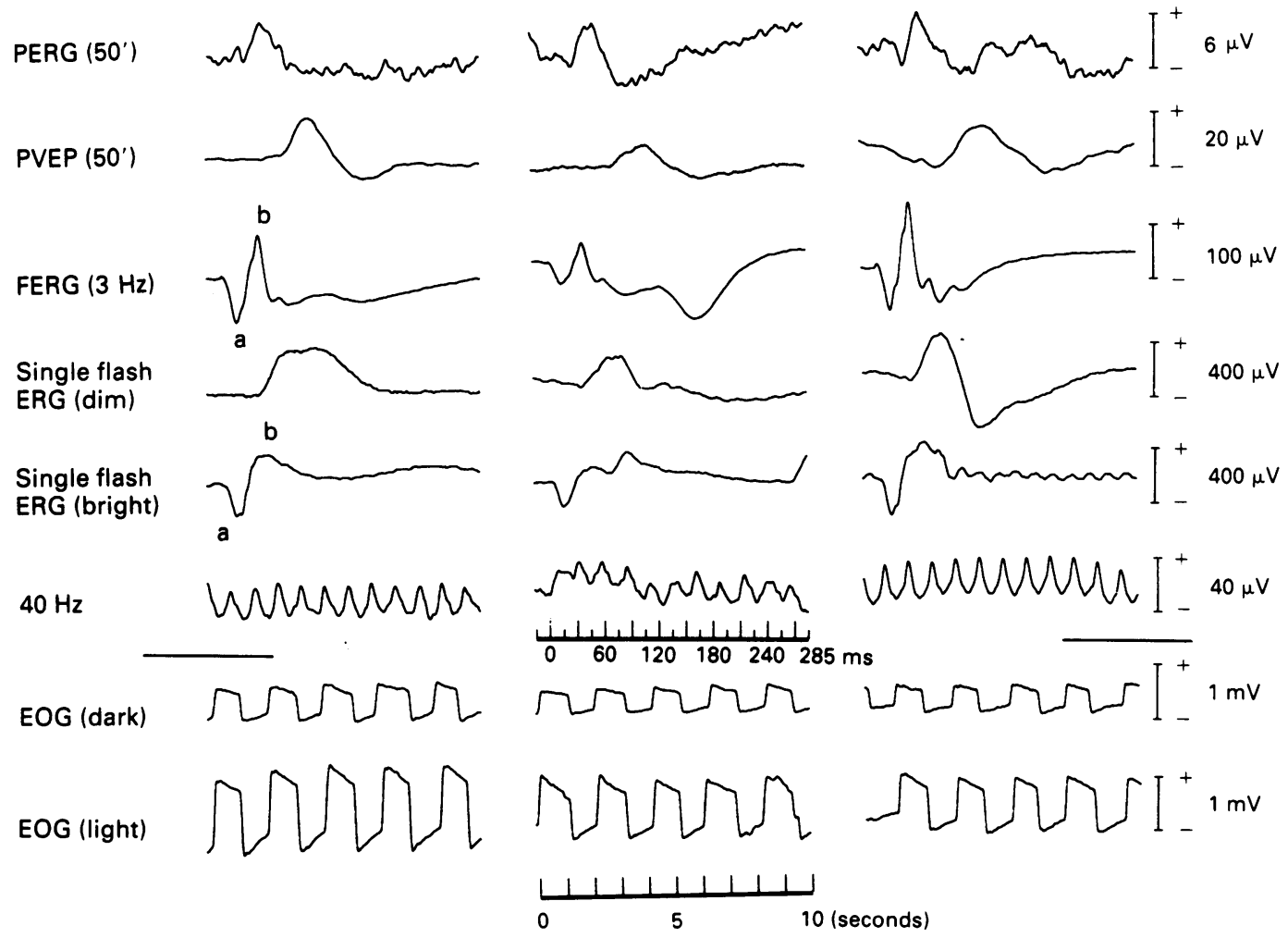

Figure 6 Examples of electroretinogram (ERG), visual evoked potential (VEP), and electro-oculogram (EOG) tracings from a 23-year-old normal control (female, aged 23) (far left column), case 6 who was in renal failure (male, 211/2 years) (middle column), and case 11 who had normal renal function (female, $11^{1 / 2}$ years) (far right column). 
were abnormal in two of the patients and one had a depigmented area in the temporal retina. The authors concluded that these patients had a retinopathy affecting only the retinal pigment epithelium. Perrin et al ${ }^{7}$ reported one patient out of seven with both a subnormal EOG light rise and a subnormal ERG amplitude. Neither study reported the renal status of those patients with abnormal EOGs.

It is possible the reduced pattern VEP amplitudes in four of our patients may be due to ocular effects associated with renal dysfunction. Cases 1 and 5 had mild posterior subcapsular cataracts and cases 4 and 20 both had an oil droplet reflex on retinoscopy, an early sign of anterior lenticonus. In cases 1 and 4 , the cataract and oil droplet may have degraded the sharpness and contrast of the checkerboard pattern to a significant extent and thus reduced the pattern VEP amplitude. However, in two other cases (Nos 5 and 20) their effect may have been much milder as pattern VEPs were of normal size.

A history of renal insufficiency was present in three of the four cases with reduced VEP responses. Case 1 had received two renal transplants, the second one being successful. Cases 6 and 12 were in chronic renal failure at the time of testing, and case 4 had normal renal function. While reduced VEP amplitudes have been reported in patients suffering chronic renal failure and in those undergoing dialysis, ${ }^{33} 34$ significantly increased pattern and flash VEP latencies are the more common finding. ${ }^{33-37}$

In conclusion, children and adolescent patients with Alport's syndrome appear not to show consistent ERG, VEP, or EOG abnormalities. Electrophysiological changes previously described in Alport's syndrome may, in part, be secondary to renal dysfunction, and future studies should address this possibility.

We would like to thank the Wooden Spoon Society and the IRIS Fund for their financial support. We also thank Mr Lawrence Nell for translation of references 12 and 21 .

1 Flinter FA, Cameron JS, Chantler C, Houston I, Bobrow $M$. Genetics of classic Alport's syndrome. Lancet 1988; ii: 1005-7.

2 Atkin CL, Hasstedt SJ, Menlove L, Cannon L, Kirschner N, Schwartz C, et al. Mapping of Alport syndrome to the long arm of the X chromosome. Am F Hum Genet 1988; 42:

3 Barker DF, Hostikka SL, Zhou J, Chow LT, Oliphant AR, Gerken SC, et al. Identification of mutations in the COL4AS collagen gene in Alport syndrome. Science 1990; 248: $1224-6$.

4 Peterson WS, Albert DM. Fundus changes in the hereditary nephropathies. Trans Am Acad Ophthalmol Otolaryngol 1974; 78: 762-71.

5 Polak BCP, Hogewind BL. Macular lesions in Alport's disease. Am f Ophthalmol 1977; 84: 532-5.

6 Nielsen CE. Lenticonus anterior and Alport's syndrome. Acta Ophthalmol (Kbh) 1978; 56: 518-30.

7 Perrin D, Jungers P, Grünfeld JP, Delons S, Noël LH, Zenatti C. Perimacular changes in Alport's syndrome. Clin Nephrol 1980; 13: 163-7

8 Zylbermann R, Silverstone BZ, Brandes E, Drukker A.
Retinal lesions in Alport's syndrome. $\mathcal{F}$ Pediatr Ophthalmol Strabismus 1980; 17: 255-60.

9 Gubler M, Levy M, Broyer M, Naizot C, Gonzales G, Perrin $D$, et al. Alport's syndrome: a report of 58 cases and a review of the literature. Am $\mathcal{F} M e d 1981 ; 70: 493-505$.

10 Govan JAA. Ocular manifestation of Alport's syndrome: hereditary disorder of basement membranes? $\mathrm{Br} \mathcal{F ~ O p h}$ thalmol 1983; 67: 493-503.

11 Gelisken Ö, Hendrikse F, Schröder CH, Berden JHM. Retina abnormalities in Alport's syndrome. Acta Ophthalmol 1988, 66: 713-7.

12 Hochgesand P, Steinbach PD, Straub E. Augenveränderungen bei Alport-Syndrom. Klin Monatsbl Augenheilkd 1974; $165: 447-52$.

13 Setälä K, Russuvaara P. Alport syndrome with hereditary macular degeneration. Acta Ophthalmol 1989; 67: 408-14.

14 Gretz N, Broyer M, Brunner FP, Brynger H, Donckerwolcke RA, Jacobs C, et al. Alport's syndrome as a cause of renal failure in Europe. Pediatr Nephrol 1987; 1: 411-5.

15 Thompson SM, Deady JP, Willshaw HE, White RHR. Ocula signs in Alport's syndrome. Eye 1987; 1: 146-53.

16 Lyon MF. Lyonisation of the X chromosome. Lancet 1963; ii $1120-1$.

17 Flinter F, Chantler C. Alport's syndrome: inheritance and clinical features. In: Spitzer A, Avner E, eds. Topics in renal medicine: hereditary nephropathies. Boston/Dordrecht London: Kluwer, 1990: 107-20.

18 Faggioni R, Scouras J, Streiff EB. Alport's syndrome: clinicopathological considerations. Ophthalmologica 1972; 165: patho $1-14$.

19 Sabates R, Krachmer JH, Weingeist TA. Ocular findings in Alport's syndrome. Ophthalmologica 1983; 186: 204-10.

20 Davies PD. Pigment dispersion in a case of Alport's syndrome. Br f Ophthalmol 1970; 54: 557-61.

21 Huck D, Meythaler H, Rix R. Alport-Syndrom mit Hornhautbeteilgung und Veränderungen des ERG. Klin Monatsb Augenheilkd 1976; 168: 553-6.

22 Arden GB, Barrada A, Kelsey JH. New clinical test of retina function based upon the standing potential of the eye. Brf Ophthalmol 1962; 46: 449-67.

23 Trimble JL, Ernest JT, Newell FW. Electro-oculography in infants. Invest Ophthalmol Vis Sci 1977: 16: 668-70.

24 Hansen RM, Fulton AB. Corneoretinal potentials in human infants. In: Kolder HEJW, ed. Doc Ophthalmol Proc Series. The Hague: Dr Junk Publishers, 1983: 81-6.

25 Martin DA, Heckenlively JR. The normal electroretinogram Doc Ophthalmol Proc Ser 1982; 31: 135-44.

26 Fulton AB, Hansen RM. Electroretinography: application to clinical studies of infants. $\mathcal{F}$ Pediatr Ophthalmol Strabismu 1985; 22: 251-5.

27 Farkas A. ERG on patients with chronic nephropathy. In: Schmöger E, Kelsey JH, eds. Doc Ophthalmol Proc Ser 1979; 23: 149-52.

28 Perossini M, Tota G. Electroretinographic findings in chronic uraemics treated with periodic haemodialysis. Doc Oph thalmol Proc Ser 1978; 15: 257-63.

29 Svěrák J, Peregrin J, Hejcmanová D, Erben J. Long-term observation of retinal electrical activity in dialysed and rena transplantation patients. Artif Organs 1984; 8: 355-8.

30 Müller W, Haase E, Gauss J, Jung N. Investigation by means of VECP in patients with chronic nephropathy. Doc Oph thalmol Proc Ser 1979; 23: 171-5.

31 Dróbecka-Brydak E, Moszczyńska-Kowalska A. Electroretinographic studies in patients after renal transplantation. Doc Ophthalmol Proc 1979; 23: 167-70.

32 Svěrák J, Peregrin J, Hejcmanová D, Erben J, Groh J. Logistic function in analysis of the ERG in dialysed patients. Doc Ophthalmol Proc Ser 1979; 23: 153-7.

33 Walser H, Kriss A, Cunningham K, Halliday AM, Jones SJ Taube D. A multimodal evoked potential assessment of uremia. In: Nodar RH, Barber C, eds. Evoked potentials II. uremia. In: Nodar RH, Barber C, eds.

34 Kuba M, Peregrin J, Vít F, Hanušová I, Erben J. Patternreversal visual evoked potentials in patients with chronic renal insufficiency. Electroenceph Clin Neurophysiol 1983; 56 : 438-42.

35 Rossini PM, Pirchio M, Treviso M, Gambi D, Di Paolo B Albertazzi A. Checkerboard reversal pattern and flash VEPs in dialysed and non-dialysed subjects. Electroenceph Clin Neurophysiol 1981; 52: 435-44.

36 Cohen SN, Syndulko K, Rever B, Kraut J, Coburn J, Tourtellotte $W W$. Visual evoked potentials and long latency event-related potentials in chronic renal failure. Neurology 1983; 33: 1219-22.

37 Ducati A, Cattarelli D, Cenzato M, Landi A, Edefonti A Captianio $\mathrm{L}$, et al. Changes in visual evoked potentials in children on chronic dialysis treatment. Childs Nerv Sys 1985; 1: 282-7. 